\section{$1 \mathrm{P321}$}

\section{タンパク質分子の機能動態を捉える高速AFMの開発}

○古寺 哲幸 ${ }^{1}$ 、宮城 篤 ${ }^{1}$ 、山下 集人 ${ }^{1}$ 、中北 諒 $^{1}$ 、坂下 満 ${ }^{1} 、$ 伊藤 悠徳 1 、内橋 貴之 ${ }^{1,2}$ 、安藤 敏夫 ${ }^{1,2,3}$ (1 金沢大・理・物 理、 ${ }^{2} \mathrm{JST} \cdot \mathrm{CREST} 、{ }^{3}$ 金沢大・フロンティア)

タンパク質分子の動作の仕組みを理解するには、機能している最中 のタンパク質分子の構造形態を捉えることが重要である。それには、 “高い空間分解能”と “生理現象を捉えるに有効な時間軸”を併せ 持った革新的な技術の開発が望まれている。その技術となる可能性を 持つ顕微鏡として、原子間力顕微鏡（AFM）がある。AFMは、水溶 液中に存在する生きたタンパク質分子をナノ解像度で観察することを 可能にした唯一の顕微鏡である。しかしながら、従来型のAFMはそ の大きな機械系の安定な動作を得るために低い走査速度が要求され、 1 枚の画像を得るために分のオーダーの時間を要してしまうという久 点を持っていた。AFM の特徴を最大限に引き出すには、その走査速 度を飛躡的に向上させる必要がある。そこで、我々はAFMに含まれ る全てのデバイスの高速化に取り組み、高速 AFMを世界に先駆けて 開発した。その結果、水溶液中でマイカ上に緩やかに固定されたミオ シンV分子のナノ動態を $80 \mathrm{~ms} /$ frame の映像として捉えることに成 功した (T. Ando et al. (2001) PNAS 98, 12468)。その後、フィー ドバック带域の向上、探針一試料間に働く力の軽減、Caged 光分解光 学系の導入など、いくつかの改良に取り組み、高速 AFM の性能は着 実に向上してきている。現在、その高速 AFM を用いて、モータータ ンパク質や分子シャペロンを中心にタンパク質分子の機能動態の観 察に取り組んでいる。当日は、現在の高速AFMの性能を示し、高速 AFM が捉えた液中ナノメートル世界で機能するタンパク質分子の映 像を紹介したい。

$\overline{\text { N. Kodera, A. Miyagi, H. Yamashita, R. Nakakita, M. Sakashita, H }}$ Ito, T. Uchihashi and T. Ando : Development of a high-speed atomic force microscope for imaging of dynamic behavior of protein molecules

\section{$1 \mathrm{P} 323$}

\section{溶液中 Pulsed-Force-Mode を利用した分子マッピ ング}

○春田 洋孝 ${ }^{1}$ 、森居 隆史 ${ }^{1}$ 、吉村 成弘 ${ }^{2}$ 、岡田知子 ${ }^{3}$ 、小川

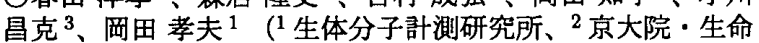
科学・分子情報、 ${ }^{3}$ 産総研・生物機能工学)

AFM を Pulsed-Force-Mode (PFM) で使用し分子マッピングを試み た。PFM とは、カンチレバーを $\sin$ 波で振動させ、試料への接触・解 離を繰り返しながら測定するモードであり、基本的にはフォースカー ブを全ピクセルで得る事と同等である。Force Volume では数時閒か ら数 10 時間かかる測定を数 10 分で行うことができ、 1 回の測定で 記録した情報を解析することにより、同一視野のトポイメージや機械 的特性、分子間結合力などの多くの情報を得ることが可能である。 HeLa 細胞表面には CD44 分子が発現している事が知られている。カ ンチレバーに抗 CD44 抗体を結合させ HeLa 細胞表面の溶液中 PFM による測定を行った(図 A、B)。またネガティブコントロールとして カンチレバーに標準 IgG を結合させて同様の湘定を行った (図C、 D)。図 A、C は Deflection 像であり図 B、Dは結合カイメージであ

測定ではネガティブコント ロールと比べるより高頻 度に結合力が検出されてお り、CD44 分子の存在を検 出したことが示唆された。 この研究は一部、新エネル キー・産業技術䌏合開発機 構 (NEDO) バイオ・IT 融 合機器開発プロジェクトの 助成によって行われたもの である。

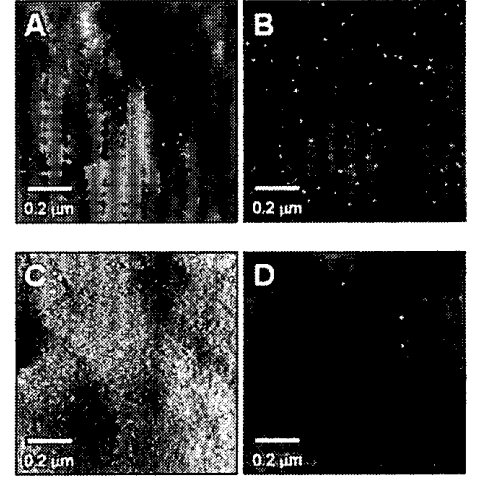

H. Haruta, T. Morii, Shige H. Yoshimura, T. Okada, Y. Ogawa and T. Okada : Molecular mapping using Pulsed-Force-Mode AFM in solution

\section{P322}

高速 AFMによるダイニンCの動態観察

○宮城 篤 1 、古寺 哲幸 ${ }^{1} 、$ 柛原 斉 ${ }^{2} 、$ 大岩 和弘 2 、安藤 敏夫 ${ }^{1,3}$ (1 金沢大院・自然科学、 ${ }^{2}$ 情報通信研究機構、 ${ }^{3}$ CREST/JST) モータータンパク質は ATPase 反応に共役してその構造を変化させる ことで機能を発現していると考えられている。そのためモータータ ンパク質の機能の解明には “動的な構造情報”を得ることが重要であ る。それには、“高い空間分解能” “ “生理現象を捉えうる時間分解 能”を併せ持つ観察手法が必要である。我々はその革新的技術となる 高速 AFM を開発し、80ms/frameのイメージング速度でモータータ ンパク質の動きを追うことが可能になった。我々は、この高速 AFM を用いてダイニンCの動態観察を行ってきた。ダイニンCは ATP 加 水分解サイクル中に、ステムーストーク間の角度が变化することが示 唆されている。これは、バナジウム酸塩を用いて、ATP 加水分解サ イクルの中間状態で止めたダイニンCを観察することで得られた結果 である (Stan A. Burgess et al. (2003)Nature 421, 715-718)。我々は この角度变化を動的に捉えることを目的に観察を行い、観察例は少な いながらもダイニンC 1 分子が運動する様子の連続撮影に成功した。 この観察では、ステムが規則的に運動する様子が観察された、また その運動の頻度はダイニンCの ATPase レートとほぼ一致している。 現在、観察例を増やすとともに、ATP 港度依存性、ステムーストーク 間の角度分布、ステムの可動範囲を調べることを目的に実蹹を行って いる。

A.Miyagi, N.Kodera, H.Sakakibara, K.Oiwa, T.Ando : Dynamic behavior of dynein c captured by high-speed AFM

\section{P324}

\section{シャペロニン GroELに起こる構造変化の高速 AFM による解析}

○谷口 雅昭 ${ }^{1}$ 、宮城 篤 ${ }^{1}$ 、古寺 哲幸 ${ }^{1}$ 、安藤 敏夫 ${ }^{1,2} \quad{ }^{1}$ 金沢 大院・自然科学、 ${ }^{2} \mathrm{CREST} / \mathrm{JST}$ )

原子間力頭薇鏡 (AFM) は, 生体分子を 1 分子レベルで直接観察で きる鬿力的な装置であるが, 従来の AFM では走査速度が遅く分子プ ロセスを観察できない。当研究室において開発された高速 AFM は非 常に素早いタンパク質分子の振る舞いを捉えることを初めて可能にし た。我々は，この高速 AFM を用いてタンパク質のフォールディング の補助を行う分子シャペロン GroE システムの観察を陚みた。

大腸菌由来のシャペロニン GroEL は, ATP 結合によりアピカルドメ インに大規模な構造変化を起こすことが知られている。これらの構造 変化が起きると，標的タンパク質は GroEL 内部に取り込まれる。更 に補助タンパク質である GroES が結合することにより，キャビティー 内部に包埋されフォールディングが進行すると考えられている。シャ ペロニンの反応機構を理解する上で重要であると考えられるATP 結 合から GroES との複合体形成までに生じる GroEL の構造变化に着目 して動態イメージングを行った。

GroEL タンパク質は，マイカに吸着させた。ATP または ADP 存在 下では, ヌクレオチド結合によって引き起こされた GroEL の構造変 化に由来すると考えられる高さの変化が観察された。また, GroES と GroEL の結合・解離の様子も観測することが出来た。さらに, CagedATP のフォトリシスを利用して GroES の GroEL への結合過程を観 測した。本発表では, GroEL の構造変化と GroES との相互作用過程 の詳細な解析結果を発表し,シャペロニンのメカニズムについて議論 する予定である。
M.Taniguchi, A.Miyagi, N.Kodera and T.Ando : Analysis of conformational changes in the chaperonin GroEL using high-speed AFM 